\title{
Fibrino-Purulent Necrotizing Metritis as a Post-Surgical Complication after a Prolonged Delivery in a Bitch: A Case Report
}

\author{
Laura Fresno', Alberto Marco ${ }^{2}$, M. Angeles Calvo ${ }^{3}$, Laura Santos ${ }^{4}$ \\ and Maria Montserrat Rivera del Alamo \\ ${ }^{1,4,5}$ Departament de Medicina i Cirurgia Animals, Facultat de Veterinària, Universitat Autònoma de \\ Barcelona, Spain \\ ${ }^{2,3}$ Departament de Sanitat i d'Anatomia Animals, Facultat de Veterinària, Universitat Autònoma de \\ Barcelona, Spain \\ Correspondence should be addressed to: Maria Montserrat Rivera del Alamo; \\ MariaMontserrat.Rivera@uab.cat
}

Received date: 16 March 2014; Accepted date: 25 June 2014; Published date: 11 August 2014

Academic Editor: Vasia S. Mavrogianni

Copyright (C) 2014. Laura Fresno, Alberto Marco, M. Angeles Calvo, Laura Santos and MariaMontserrat Rivera del Alamo. Distributed under Creative Commons CC-BY 3.0

\begin{abstract}
This case report describes a fibrino-purulent necrotizing metritis in a two year old female French Bulldog that appeared after performing a caesarean section because of dystocia. Four days after performing $\mathrm{C}$-section, the bitch was referred with severe metrorrhagia and dehiscence of the cutaneous incision. Metrorrhagia was treated with oxytocin without success and an ovariohysterectomy was performed. The uterine incision showed partial dehiscence of the suture and severe inflammation. In the uterine microbiologic culture isolated Escherichia coli and Proteus spp, while histology showed fibrino-purulent necrotizing metritis.
\end{abstract}

Keywords: dystocia, caesarean section, necrotizing metritis.

\section{Introduction}

Metritis is characterised by the inflammation of endometrium and myometrium that causes systemic illness in the bitch during the immediate postpartum period due to ascending bacterial invasion through the open cervix (Wheeler et al., 1984). These bacteria can thrive in retained or devitalized tissues.

Puerperal metritis is associated with dystocia, retained placentas and pups, macerated or decomposed pups, and prolonged delivery. The most frequent isolated bacteria are Escherichia coli, Proteus spp., Staphylococcus spp., and Streptococcus spp. (Magne, 1986; Wykes et al., 1993).

Clinical signs in bitches with metritis include depression, high rectal temperatures, little or non interest in the puppies, lethargia, and a purulent, foulsmelling reddish to brown vulvar discharge. These signs can induce overall

Cite this Article as: Laura Fresno, Alberto Marco, M. Angeles Calvo, Laura Santos and Maria Montserrat Rivera del Alamo (2014), "Fibrino-Purulent Necrotizing Metritis as a Post-Surgical Complication after a Prolonged Delivery in a Bitch: A Case Report", International Journal of Veterinary Medicine: Research \& Reports, Vol. 2014 (2014), Article ID 117728, DOI: 10.5171/2014.117728 
status impairment when not treated and septicaemia or toxaemia followed by the death of the animal can occur.

In human, the incidence of post-partum metritis after vaginal delivery ranges from 0,9\% to 3.9\% (Mead et al., 1997; Ernest and Mead, 1998), whereas the rate of postcaesarean metritis ranges from $5 \%$ or less for elective procedures to as high as 95\% for nonelective caesarean sections performed in certain high-risk populations (Casey et al., 1997; Mead et al., 1997; Pastoreck, 1995; Spandorfer et al., 1996; Hofmeyr and Smaill, 2002; Haas et al., 2013). According to our knowledge and the reviewed literature, metritis incidence in bitches has not been reported, although it is considered an uncommon situation.

In this paper, necrotizing a fibrino-purulent metritis after performing a caesarean section is described in a two year old bitch.

\section{Case Report}

\section{Individual information}

A 2-year-old, pregnant French Bulldog, weighing $11.9 \mathrm{~kg}$, was presented to the Fundació Hospital Clínic Veterinari because of owner-perceived dystocia. The owners suspected that the bitch had been in labour for $24 \mathrm{~h}$ without the delivery of any puppy. According to the information facilitated by the owners, the bitch had been bred with a French Bulldog male two months ago and it was its first pregnancy. No other previous reproductive control was performed as it was the first time the patient was referred to our hospital.

\section{Clinical Findings}

The bitch showed marked clinical deterioration, dyspnoea, cachexia and an excessively marked abdominal distension accompanied by pain at abdominal palpation. Body temperature was $38.4^{\circ} \mathrm{C}$, heart rate was $134 \mathrm{bpm}$ and respiratory rate was 48 . In addition, the patient showed $6 \%$ of dehydration. Manual examination of the vagina revealed a puppy located in the pelvic cavity and absence of Ferguson reflex. The puppy located in the birth canal showed an anterior presentation, dorsal position, and flexed posture of the fore limbs, preventing the obstetrical manipulation to pull it out. Abdominal ultrasonography revealed the presence of foetal stress in the puppies evaluated as showed by heart rate under $160 \mathrm{bpm}$. Complete cell blood count (CBC) (Table 1 ) revealed a mild anaemia with a red blood cell count of $5.08 \cdot 10^{6} / \mu \mathrm{L}$ (reference range: 5.5 to $8.5 \cdot 10^{6} / \mu \mathrm{L}$ ) and haemoglobin concentration of $11.8 \mathrm{~g} / \mathrm{dL}$ (reference range: 12 to $18 \mathrm{~g} / \mathrm{dL}$ ) both associated to pregnancy. Leukopenia of $4.88 \times 10^{9} / \mathrm{L}$ (reference range 5.5 to 16.9 $\left.\mathrm{x} 10^{9} / \mathrm{L}\right)$ with lymphopenia of $0.32 \times 10^{9} / \mathrm{L}$ (reference range 0.5 to $4.9 \times 10^{9} / \mathrm{L}$ ) was also present. Complete biochemical profile was found to be normal (Table 1).

Table 1: Complete cell blood and biochemical profile previous to C-section

\begin{tabular}{|l|c|c|}
\hline Parameter & Reference range & Patient values \\
\hline RBC (M/?L) & $5.50-8.50$ & 5.08 \\
\hline HTC (\%) & $37.0-55.0$ & 36.0 \\
\hline HGB (g/dL) & $12.0-18.0$ & 11.8 \\
\hline WBC (K/国) & $5.50-16.90$ & 4.88 \\
\hline Neutrophils (K/?L) & $2.00-12.00$ & 3.89 \\
\hline Lymphocytes (K/? $\mathrm{L})$ & $0.50-4.90$ & 0.32 \\
\hline Monocytes (K/?L) & $0.30-2.00$ & 0.61 \\
\hline Eosinophils (K/?L) & $0.10-1.49$ & 0.02 \\
\hline Basophils (K/?L) & $0.00-0.10$ & 0.04 \\
\hline Platelets (K/?L) & $175-500$ & 623 \\
\hline Glucose (mg/dL) & $74-143$ & 88 \\
\hline BUN (mg/dL) & $7-27$ & 18 \\
\hline
\end{tabular}




\begin{tabular}{|l|c|c|}
\hline Creatinin (mg/dL) & $0.5-1.8$ & 1.4 \\
\hline Total proteins (g/dL) & $5.2-8.2$ & 7.8 \\
\hline Albumin (g/dL) & $2.3-4.0$ & 2.9 \\
\hline Globulin (g/dL) & $2.5-4.5$ & 4.9 \\
\hline $\mathrm{ALT}(\mathrm{U} / \mathrm{L})$ & $10-100$ & $<10$ \\
\hline $\mathrm{ALKP}(\mathrm{U} / \mathrm{L})$ & $23-212$ & $<10$ \\
\hline $\mathrm{Na}(\mathrm{mmol} / \mathrm{L})$ & $144-160$ & 155 \\
\hline $\mathrm{K}(\mathrm{mmol} / \mathrm{L})$ & $3.5-5.8$ & 3.9 \\
\hline $\mathrm{Cl}(\mathrm{mmol} / \mathrm{L})$ & $109-122$ & 118 \\
\hline
\end{tabular}

\section{Surgical and Therapeutic Schedule}

The dog was prepared for emergency caesarean section. Isotonic crystalloid solution was administrated at a rate of 10 $\mathrm{mL} / \mathrm{kg} \cdot \mathrm{h}$ and broad-spectrum antibiotic therapy consisted of an IV injection of cephalexin $(22 \mathrm{mg} / \mathrm{kg})$. Anaesthesia was induced with IV buprenorphine $(20 \mu \mathrm{g} / \mathrm{kg})$ and propofol ( $4 \mathrm{mg} / \mathrm{kg})$, and maintained on inhalant isofluorane in oxygen through a semi-opened anaesthetic system. Surgical field was aseptically prepared with chlorhexidine and alcohol.

A caesarean section was performed by ventral midline laparotomy. Uterus was isolated with sterile surgical drapes to avoid leakage to the abdominal cavity. Through the uterine incision localized in the ventral uterine body, a total of 11 foetuses with their respective placentae were removed. The uterus aspect was macroscopically normal.

The foetus in the pelvic cavity was dead and presented with anasarca (hydrops foetalis). Routine resuscitation procedures were performed in the rest of the puppies delivered but only one survived. The Csection was closed using a two-layer suture pattern (simple continuous followed by Cushing) with synthetic monofilament glyconate 3/0 USP suture material. The laparotomy was closed in a routine manner. The bitch and the puppy were discharged 8 hours after surgery when the mother was fully recovered from anaesthesia, cardiovascularly stable, mentally alert, and appeared to have adequate milk production. Prophylactic antibiotic consisting on amoxicillin 20 $\mathrm{mg} / \mathrm{kg}$ PO q12h during 10 days was established.

Eight hours after discharge, the bitch was presented again to the hospital for further evaluation because of the onset of tremors and restlessness. Rectal temperature was $39.3^{\circ} \mathrm{C}$. Heart rate was $120 \mathrm{bpm}$ and respiratory rate was $38 \mathrm{rpm}$. Membrane mucosa looked pink. There was a slight haemorrhagic vaginal discharge considered normal after delivery. Mammary gland showed normal development and good milk production. Surgery wound aspect was completely normal. The owners reported that the puppy was doing well. $\mathrm{CBC}$ and complete biochemical profile was performed (Table 2) and showed moderate anaemia with a red blood cell count of $3.54 \cdot 10^{6} / \mu \mathrm{L}$ and haemoglobin concentration of $8.8 \quad \mathrm{~g} / \mathrm{dL}$. Hypoproteinemia of $4.8 \mathrm{~g} / \mathrm{dL}$ (reference range: 5.2 to $8.2 \mathrm{~g} / \mathrm{dL}$ ) with a hypoalbuminemia of $1.9 \mathrm{~g} / \mathrm{dL}$ (reference range: 2.3 to $4 \mathrm{~g} / \mathrm{dL}$ ) was also present. WBC value normalized to $7,56 \times 10^{9} / \mathrm{L}$. Venous blood gas analysis was normal and an ionized fraction of calcium of 0.72 $\mathrm{mmol} / \mathrm{L}$ (reference range: 1.25 to 1.50 $\mathrm{mmol} / \mathrm{L}$ ) was detected indicating severe hypocalcemia. The animal was hospitalized for the treatment of hypocalcemia with 0.5 $\mathrm{mg} / \mathrm{kg}$ of IV calcium gluconate administered slowly over 30 minutes. Then, $50 \mathrm{mg} / \mathrm{kg}$ q8h of PO calcium carbonate were administered once the bitch was stabilized. Two days later, when calcium levels were stabilized (1.34 $\mathrm{mmol} / \mathrm{L}$ ), the animal was discharged with PO calcium treatment and scheduled for calcium levels' determination in two days. The puppy was allowed to nurse from the dam. 
Table 2: Complete cell blood and biochemical profile

\begin{tabular}{|c|c|c|}
\hline Parameter & Reference range & Patient values \\
\hline RBC (M/?L) & $5.50-8.50$ & 3.54 \\
\hline HTC (\%) & $37.0-55.0$ & 26.2 \\
\hline $\mathrm{HGB}(\mathrm{g} / \mathrm{dL})$ & $12.0-18.0$ & 8.8 \\
\hline WBC $(\mathrm{K} /$ 圆 $\mathrm{L})$ & $5.50-16.90$ & 7.56 \\
\hline Neutrophils (K/国L) & $2.00-12.00$ & 5.75 \\
\hline Lymphocytes (K/司) & $0.50-4.90$ & 1.12 \\
\hline Monocytes (K/?L) & $0.30-2.00$ & 0.55 \\
\hline Eosinophils (K/国L) & $0.10-1.49$ & 0.09 \\
\hline Basophils (K/回) & $0.00-0.10$ & 0.05 \\
\hline Platelets (K/回) & $175-500$ & 455 \\
\hline Glucose $(\mathrm{mg} / \mathrm{dL})$ & $74-143$ & 113 \\
\hline BUN (mg/dL) & $7-27$ & 17 \\
\hline Creatinin (mg/dL) & $0.5-1.8$ & 0.7 \\
\hline Phosphorus (mg/dL) & $2.5-6.8$ & 2.7 \\
\hline Ionized calcium (mmol/L) & $1.25-1.50$ & 0.72 \\
\hline Total proteins $(\mathrm{g} / \mathrm{dL})$ & $5.2-8.2$ & 4.8 \\
\hline Albumin (g/dL) & $2.3-4.0$ & 1.9 \\
\hline Globulin (g/dL) & $2.5-4.5$ & 2.9 \\
\hline $\operatorname{ALT}(\mathrm{U} / \mathrm{L})$ & $10-100$ & $<10$ \\
\hline $\operatorname{ALKP}(\mathrm{U} / \mathrm{L})$ & $23-212$ & 239 \\
\hline GGT (U/L) & $0-7$ & 1 \\
\hline Cholesterol (mg/dL) & $110-320$ & 169 \\
\hline $\mathrm{Na}(\mathrm{mmol} / \mathrm{L})$ & $144-160$ & 144 \\
\hline $\mathrm{K}(\mathrm{mmol} / \mathrm{L})$ & $3.5-5.8$ & 3.5 \\
\hline $\mathrm{Cl}(\mathrm{mmol} / \mathrm{L})$ & $109-122$ & 109 \\
\hline
\end{tabular}

However, 2 days later the bitch was presented again with profuse metrorrhagia and skin and subcutaneous wound dehiscence. The vaginal discharge was clearly haemorrhage and not lochia. Rectal temperature was $38.3^{\circ} \mathrm{C}$. Heart rate was $132 \mathrm{bpm}$. Membrane mucosa looked pale. CBC (Table 3) was repeated and revealed moderate anaemia with a red blood cell count of $3.58 \cdot 10^{6} / \mu \mathrm{L}$ and haemoglobin concentration of $8.3 \quad \mathrm{~g} / \mathrm{dL}$. Hypoproteinemia of $5.8 \mathrm{~g} / \mathrm{dL}$ and recurrent hypocalcemia with an ionized calcium concentration of $0.82 \mathrm{mmol} / \mathrm{L}$ was present. Treatment of hypocalcemia with IV calcium gluconate $(0.5 \mathrm{mg} / \mathrm{kg})$ injected slowly over 30 minutes was administered again. Abdominal ultrasonography revealed a distended uterus filled with heterogeneous fluid collection and thickened uterine walls suggesting metritis. A small content of free peritoneal fluid was also appreciated. Ovariohysterectomy was proposed to the owners but they rejected that option and asked for a conservative treatment. In order to control uterine haemorrhage, IM oxytocin (0.5 UI $/ \mathrm{kg})$ was administrated and repeated after 6 hours. Antibiotic therapy with cephalexin $(20 \mathrm{mg} / \mathrm{kg})$ was also initiated. Because of the unsuccessful control of metrorrhagia after 6 hours of the second oxytocin injection, vaginoscopy/hysteroscopy and/or emergency surgery was finally allowed by the owners. 
Table 3: Complete cell blood and biochemical profile

\begin{tabular}{|c|c|c|}
\hline Parameter & Reference range & Patient values \\
\hline RBC (M/回L) & $5.50-8.50$ & 3.58 \\
\hline HTC (\%) & $37.0-55.0$ & 23.3 \\
\hline HGB (g/dL) & $12.0-18.0$ & 8.3 \\
\hline WBC (K/目L) & $5.50-16.90$ & 11.28 \\
\hline Neutrophils (K/国L) & $2.00-12.00$ & 6.37 \\
\hline Lymphocytes (K/司) & $0.50-4.90$ & 2.98 \\
\hline Monocytes (K/目L) & $0.30-2.00$ & 1.40 \\
\hline Eosinophils (K/国L) & $0.10-1.49$ & 0.17 \\
\hline Basophils (K/回L) & $0.00-0.10$ & 0.21 \\
\hline Platelets (K/回L) & $175-500$ & 445 \\
\hline Glucose (mg/dL) & $74-143$ & 107 \\
\hline Ionized calcium (mmol/L) & $1.25-1.50$ & 0.82 \\
\hline
\end{tabular}

The animal was premedicated with subcutaneous morphine $(0.4 \mathrm{mg} / \mathrm{kg})$, induction was performed with propofol (4 $\mathrm{mg} / \mathrm{kg})$ and diazepam $(0.5 \mathrm{mg} / \mathrm{kg})$ and maintained with isofluorane in oxygen. Before surgery, vaginoscopy using a $30^{\circ} 2.7$ $\mathrm{mm}$ telescope was performed in order to detect the probable source of haemorrhage. Blood clots were observed and, due to the open cervix, suture dehiscence of the uterine surgical wound was appreciated. Remnants of foetal membranes were not observed. Ventral midline laparotomy was performed and strong adherences of the uterus to the muscular layer and the omentum were found (Fig.1) as well as free peritoneal fluid. After careful dissection of adherences, rupture of part of the surgical wound of the C-section was observed as well as suture dehiscence and abundant granulation tissue (Fig. 2). Ovariohysterectomy was performed conventionally, peritoneal cavity was washed abundantly with 1,5 litres of warm sterile saline solution and after devitalized tissue of the muscular, subcutaneous and skin was removed, laparotomy was routinely closed. Tissue samples from the uterus were submitted for culture and histological evaluation.

The animal recovered uneventfully and was discharged $24 \mathrm{~h}$ after surgery with analgesic and antibiotic therapy consisting on tramadol $2 \mathrm{mg} / \mathrm{kg}$ q8h $\mathrm{PO}$ and cephalexin 20mg/kg q12h P0, respectively.
Culture of the uterine secretions obtained after surgery yielded growth of Proteus spp. and Escherichia coli, both of which were resistant and sensible, respectively, to cephalexin. Antibiogram results were obtained 6 days after last surgery and, due to the clinical improvement of the dog during this time period, the fact that she was still lactating, and the difficulty to administer another antibiotic by other route different from the oral one, cephalexin was maintained until skin staples' removal.

Histology revealed a severe purulent and necrotizing metritis with intense accumulation of degenerated neutrophils in the mucosa that caused an evident endometrial disruption. The mesentery adjacent to the uterus showed an intense and severe purulent necrotizing inflammation associated with zones of septal fibrosis and presence of granulation tissue on serosal surface (Fig.3).

\section{Discussion and Conclusions}

Metritis and infection of the surgical incision in women account for nearly three fourths of post-caesarean infections, most of them are found to be surgical site related, with $55 \%$ classified as uterine in origin and 19\% classified as arising from the surgical incision (Horan et al., 1993). The latter complicates approximately 5\% to $8 \%$ of caesarean deliveries (Normand et al., 2001). This case report describes a severe diffuse fibrino-purulent necrotizing 
metritis with subsequent uterine rupture following a caesarean section in a bitch. The prolonged labour and dystocia, probably associated to a failed delivery of a puppy with foetal anasarca, could cause that presence of normal vaginal bacteria (Escherichia coli and Proteus spp.) colonizing the uterus. Indeed, postcaesarean metritis, as well as the majority of wound infections, are ascending in nature and caused by normal vaginal microorganisms entering the uterus (Normand et al., 2001; Orfanou et al., 2010). Also, a highly distended uterus caused by a pregnancy of 11 foetuses in a French Bulldog may provide an ideal culture medium susceptible to bacterial colonization. Additionally, a possible suture material rejection, maybe enhanced by the presence of infection, as a promoting cause of suture dehiscence could not be discarded either, as the same suture material was used for the closure of the uterus, skin and subcutaneous tissue, but not for the muscular layer, which appeared intact. Nevertheless, during surgery, bacteria can be transported by foetal fluids not only to the uterine incisions, but also to the abdominal incisions (Normand et al., 2001). This could also explain why dehiscence of the skin and subcutaneous tissue occurred. Although samples for bacterial culture from these tissues were not collected, one may expect that surgical contamination of skin and subcutaneous tissue could easily happen during foetal delivery by c-section.

Hypocalcemia in bitches can occur prior to parturition, as it occurs in cows, but it is much more common during the first weeks of the post-partum (Kaufman, 1986), being more frequent in the bitches of small breeds, (Burke, 1977; Martin and Capen, 1980; Mosier, 1980; Johnston, 1983; Feldman, 1995). Both clinical and subclinical hypocalcemia has been associated to metritis in cows (Curtis et al., 1983; Martinez et al., 2012). The hypothetical mechanism is based on the fact that hypocalcemia decreases smooth muscle tone which in turn would increase the risk of metritis (Goff and Horst, 1997; Martínez et al., 2012) and placenta retention (Curtis et al., 1983). According to the reviewed literature, hypocalcemia has not been determined as causing metritis in bitches, although this possibility should be taken into account. However, in the present clinical case a more feasible reason for metritis would be the primary uterine inertia induced by an elevated number of foetuses that would overstretches the uterus. The lack of uterine contractions prevented the delivery of the foetuses and allowed the entrance of vaginal microorganisms into the uterus that would induce metritis.

Puerperal haemorrhage can occur in animals with coagulation disorders. Rarely, it can be the result of erosion of large blood vessel(s) in case of subinvolution of placental sites. It may also be due to uterine rupture, to venereal neoplasms or to vaginal injuries (Orfanou et al., 2010). Initial treatment of cases of mild haemorrhage includes administration of oxytocin (5 to $20 \mathrm{IU} / \mathrm{kg}$, intramuscularly) and the general support of the animal (Orfanou et al., 2010). In cases of severe haemorrhage or when after oxytocin administration haemorrhage persists, ovariohysterectomy is indicated after the animal's condition is stabilized.

Because of the owners' willingness to preserve the reproductive function of the animal and in order to identify and detect the possible source of haemorrhage, a vaginoscopy was performed. However, during the procedure, an active haemorrhage was not identified, but loose suture material in the uterine incision was observed and an exploratory laparotomy was decided followed by an ovariohysterectomy. Pneumoperitoneum was not induced probably due to the seal provided by the presence of adherences between the uterine incision and the muscular wall.

Amoxicillin is a safe antibiotic for lactating puppies and is a good choice when Csection shows no complications. In the present case, C-section surgery was completely routine and amoxicillin therapy for 10 days was decided. However, when metritis was diagnosed, amoxicillin was replaced by cephalexin which is a wider broad antibiotic and also safe for lactating puppies. Sensitivity test showed that cephalexin was effective against Escherichia coli but not Proteus spp, both 
obtained from uterine secretions. Of course, lactation could be suspended and feed the puppy with artificial feeding and administrate a more sensitive antibiotic. However, the good recovery of the bitch indicated that the therapy was effective and the antibiotic was not changed.

Thus, although in bitches, metritis is usually induced by foetal membranes or foetuses retention (Burke,1977; Boscos et al.,1996; Linde-Forsberg, 2005), in this case report, we could conclude that metritis was induced by a prolonged delivery that facilitated the ascending colonization of bacteria from the vagina. The metritis promoted the dehiscence of the uterine surgical incision to occur. The infection probably spread to the subcutaneous tissue and abdominal cavity during the surgery and following uterine rupture, respectively. Peritonitis caused by uterine rupture was kept circumscribed due to omental and peritoneal adherences.

\section{References}

1. Boscos, C., Smartzi, F. (1996). "Postpartum disorders in the bitch". Bull Hell Vet Med Soc 46, 342-351.

2. Burke, T.J. (1977). "Post parturient problems in the bitch". Vet Clin N Am 7, 342-351.

3. Casey, B.M., Cox, S.M. (1997). "Chorioamnionitis and endometritis". Infectious Disease Clinics of North America 11(1), 203-222.

4. Curtis, C.R., Erb, H.N., Sniffen, C.J., Smith, S.D., Powers, P.A., Smith, M.C., White, M.E., Hillman, R.B., Pearson, E.J. (1983). Association of parturient hypocalcemia with eight periparturient disorders in Holstein cows. J. Am. Vet. Med. Assoc., 183, pp. 559-561.

5. Goff, J.P., Horst, R.L. (1997). Physiological changes at parturition and their relationship to metabolic disorders. J. Dairy Sci., 80, pp. 1260-1268.

6. Haas, D.M., Morgan, S., Contreras, K. (2013). Vaginal preparation with antiseptic solution before cesarean section for preventing postoperative infections.
Cochrane Database Syst Rev., 31;1:CD007892.

7. Hofmeyr, G.J., Smaill F.M. (2002). Antibiotic prophylaxis for cesarean section. Cochrane Database Syst Rev. Issue 3:CD000933.

8. Horan, T.C., Culver, D.H., Gaynes, R.P., Jarvis, W.R., Edwards, M.S., Redi, C.R.(1993). "Nosocomial infection in surgical patients in the United States, January 1986-June 1992". Infection Control and Hospital Epidemiology 14(2), 73-80.

9. Linde-Forsberg,

C. (2005)."Abnormalities in pregnancy, parturition, and the periparturient period". In: S.J. Ettinger, E.C. Feldman, (Eds) Textbook of Veterinary Internal Medicine; $6^{\text {th }}$ edition, $1664-1667$.

10. Magne, M.L. (1986) "Acute metritis in the bitch". In: Morrow. A.D. (Ed) Current Therapy in Theriogenology; $2^{\text {nd }}$ Edition 505-506.

11. Martinez, N., Risco, C.A., Lima, F.S., Bisinotto, R.S., Greco, L.F., Ribeiro, E.S., Maunsell, F., Galvão, K., Santos, J.E.P. (2012). Evaluation of peripartal calcium status, energetic profile, and neutrophil function in dairy cows at low or high risk of developing uterine disease J. Dairy Sci., 95, pp. 7158-7172.

12. Normand, M.C., Damato, E.G. (2001). "Postcesarean Infection". Journal of Obstetric, Gynecologic, \& Neonatal Nursing $30(6), 642-648$.

13. Orfanou, D.C., Ververidis, H.N., Boscos, C.M., Fthenakis, G.C.(2010). "Post-partum pathological condition in the bitch - Part II". European Journal of Companion Animal Practice 20(2), 119-126.

14. Pastorekured, J.G. (1995)."Postcesarean endometritis". Comprehensive Therapy 21(5): 249-253.

15. Spandorfer, S.D., Graham, E., Forouzan, I. (1996). "Postcesarean endometritis: Clincial risk factors predictive of positive blood cultures". Journal of Reproductive Medicine 41(11), 797-800. 
16. Wheeler, S.L., Magne, M.L., Kaufman, J., Husted, P.A., Allen, T.A., Olson, P.N. (1984). "Postpartum disorders in the bitch". Comp. Cont. Educ. Pract. 6, 493-500.
17. Wykes, P.M., Olson, P.N. (1993) "Diseases of the uterus". In: Bojrab, M.M., Bloomberg, M.S., Smeak, D.D. (Eds) Disease Mechanisms in Small Animal Surgery; $2^{\text {nd }}$ Edition 570-573. 